\title{
New and revised Crustal and Upper mantle terraine boundaries in Southern Africa: Implications for kimberlite exploration and emplacement
}

\author{
David Khoza ${ }^{1}$ \\ ${ }^{1}$ Spectrem Air PTY LTD, davidk@spectrem.co.za
}

\section{Introduction}

It is well appreciated that crustal and lithospheric structures affect the emplacement of diamondiferous kimberlites. Certainly in Southern Africa, the majority of kimberlite clusters appear to be located in close proximity to crustal structures defined from regional magnetic data and deep probing electromagnetic data.

In this work, a new crustal and upper mantle lithospheric structure map beneath Archean and Proterozoic terraines is presented. We use deep probing magnetotelluric data to map the electrical lithosphere up to depths of over $300 \mathrm{~km}$. The new map reveals previously unknown lithosphere in places such as the Limpopo, Kaapvaal and Zimbabwe terrains and provides a targeting tool in these enigmatic terraines.

While the presence of hydrous minerals, which affect the strength of the lithosphere, was not the primary focus of the current study the presence of thick, resistive, cratonic material in some of the terraines point to rigid lithosphere that was not previously documented. A combination of paleomagnetic data, electrical structures an ages from kimbelite xenoliths could be used to provide constraints in placing the mapped terranes in the geo-tectonic framework.

\section{SAMTEX MT data for lithospheric mapping}

The magnetotelluric method is an electromagnetic (EM) sounding technique that has evolved rapidly since its first theoretical description in the 1950s. By measuring the time variations on the surface, of the horizontal electric (Ex, Ey) and horizontal and vertical magnetic ( $\mathrm{Hx}, \mathrm{Hy}$ and $\mathrm{Hz}$ ) fields induced in the subsurface, we can derive the lateral and vertical subsurface variations of electrical resistivity.

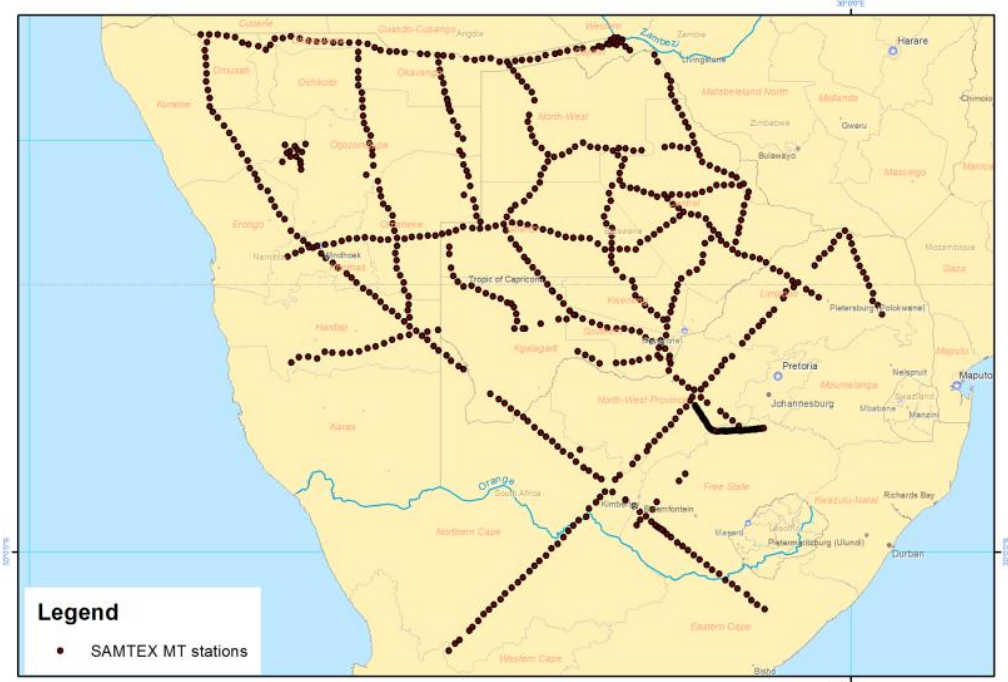

Figure 1 The location of the SAMTEX magnetotelluric station where broadband MT data were collectect in Botswana, Namibia and South Africa

In Southern Africa, we have acquired broadband (periods from $0.001 \mathrm{~s}$ to $8000 \mathrm{~s}$ ) and long period (15 $\mathrm{s}$ to over 10,000 s) magnetotelluric data as part of the SAMTEX project (Figure 1). More than 750 stations of data were collected in Namibia, Botswana and South Africa over four field seasons along 
various profiles from 2003 to 2008, with station spacings of approximately $20 \mathrm{~km}$ and $60 \mathrm{~km}$ for broadband and long period data, respectively. The orientations of the profiles were chosen to transect over specific geological features of interest.

\section{Crustal mapping (Limpopo and Orapa kimberlite field)}

The data over Limpopo belot and Kaapvaal craton were processed and modelled and the result are summarised in the 3D block below (Figure 2). The crust in the southern part of the model is dominated by resistive features in the South Marginal Zone of the Limpopo belt and the Kaapvaal craton. There is a significant resistivity break, up to $20 \mathrm{~km}$ in lateral distance, in the model that correlates spatially with the Soutpansberg basin. The location of the crustal PTSZ is characterized by a conductive signature.

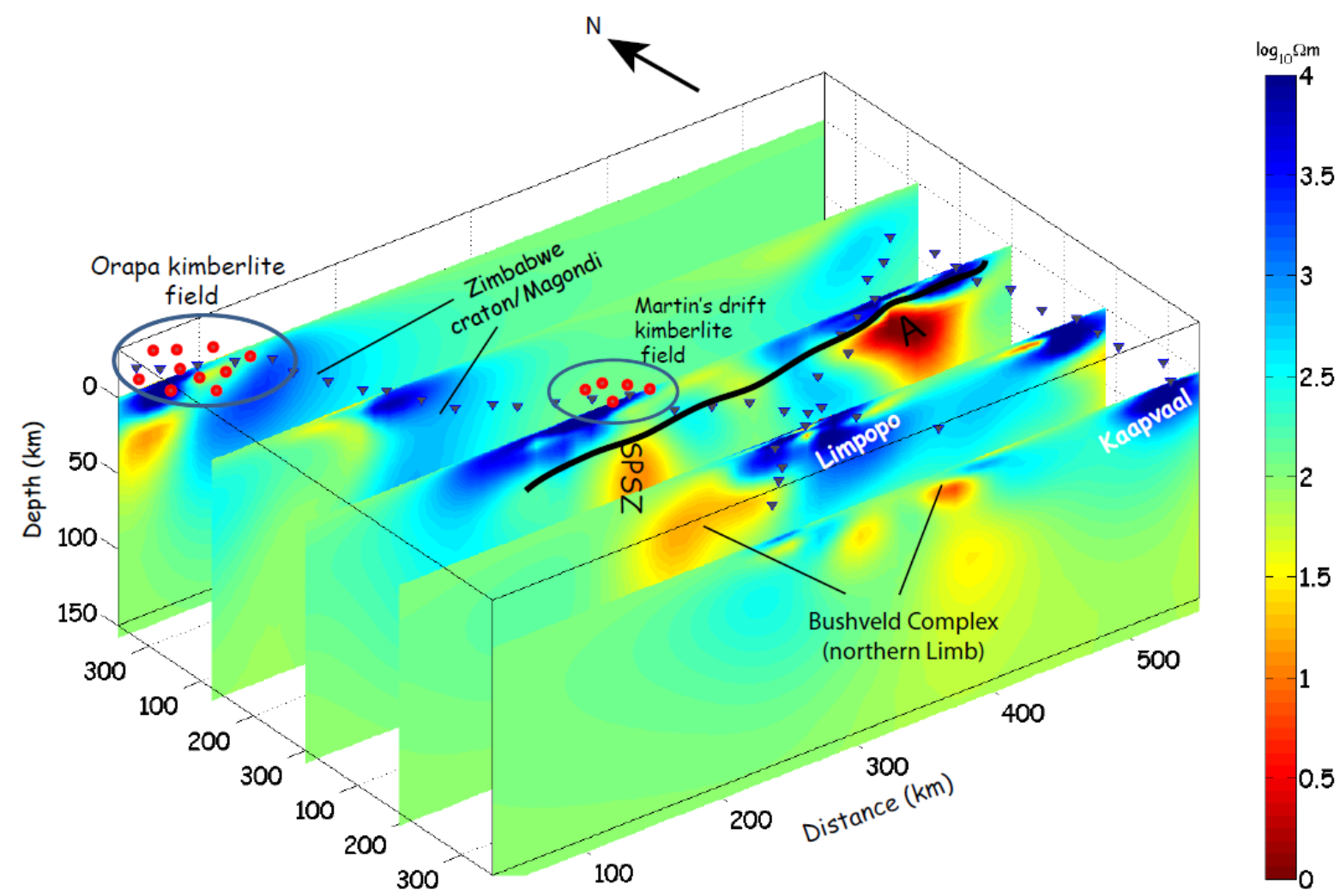

Figure 2 3D E-W perspective view showing the variation in resistivity laterally and depth across the Limpopo belt. The location of the Orapa and Martin's Drift kimberlite fields are projected. The dark solid line shows the approximate trace of the Palala-Tshipise-Sunnyside Shear system. SPSZ: Sunnyside-Palala Shear Zone.

The locations of the Martin's drift and Orapa kimberlite clusters are projected on the model and the lithosphere beneath it is characteristically resistive and thick (Figure 3). This perhaps explains the locations of these clusters being on the margins of deep crustal structures.

These data support the overiding model that diamondiferous kimberlite intrusions end to occur on the margins of cratons. 


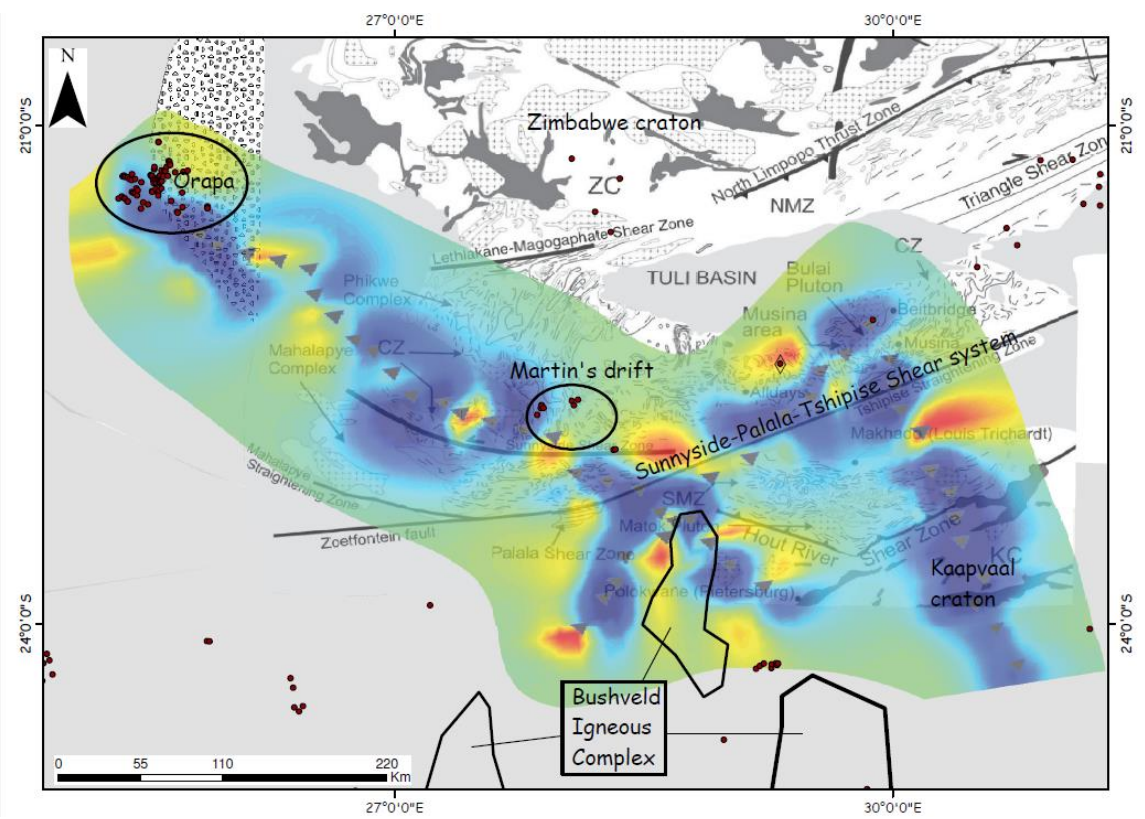

Figure 3 Crustal depth section $(10 \mathrm{~km})$ derived from 3D inversion model. The section is overlain on the geological map of the Limpopo belt (after Kramers et al., 2011). The main features are highlighted, including the locations of the Orapa and Martin's drift kimberlite fields.

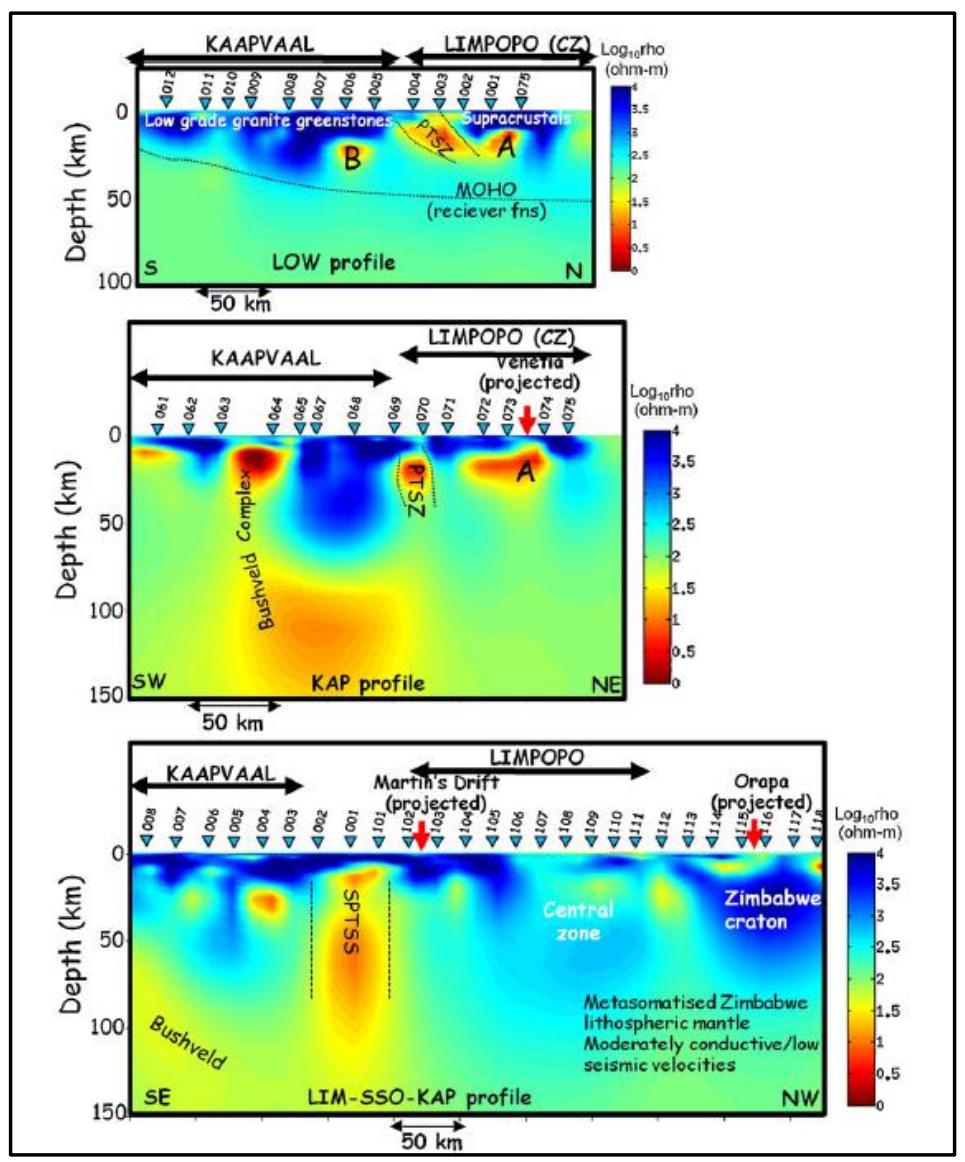

Figure 4 Three MT profiles derived from 3D inversion model. The Moho depth was derived from the seismic receiver function study of Gore et al. (2010) (note the profile depth is $100 \mathrm{~km}$ ). The location of Venetia kimberlite is projected on the KAP profile and is shown as red arrow. Similarly, the Orapa and Martin's Drift kimberlite clusters are shown on the LIM-SSO profile PTSZ: Palala-Tshipise Shear Zone, SPTSS: Sunnyside-PalalaTshipise Shear System. 


\section{References}

Gore, J., James, D.E., Zengeni, T.G., Gwavava, O., 2010. Crustal structure of the Zimbabwe craton and the Limpopo belt of Southern Africa: new constraints from seismic data and implications for its evolution. South African Journal of Geology 112, 213-228.

Kramers, J.D., McCourt, S., Roering, C., Smit, C.A., van Reenen, D.D., 2011. Origin and evolution of Precambrian high-grade Gneiss terranes, with special emphasis on the Limpopo Complex of Southern Africa. In: van Reenen, D.D., Kramers, J.D., McCourt, S., Perchuk, L.L (Eds.), Geological Society of America Memoirs, vol. 207. Geological Society of America, pp. 311-324

Khoza, D.T., Jones, A.G., Muller, M.R., Webb, S.J., 2011. The electrical lithosphere in Archean cratons: examples from Southern Africa. In: AGU Fall Meeting Abstracts, p. 2101. 